\title{
A fine-scale assessment of the ecosystem service-disservice dichotomy in the context of urban ecosystems affected by alien plant invasions
}

Luke J. Potgieter $^{1 *}$ (D, Mirijam Gaertner ${ }^{1,2}$, Patrick J. O'Farrell ${ }^{3,4}$ and David M. Richardson ${ }^{1}$

\begin{abstract}
Background: Natural resources within and around urban landscapes are under increasing pressure from ongoing urbanisation, and management efforts aimed at ensuring the sustainable provision of ecosystem services (ES) are an important response. Given the limited resources available for assessing urban ES in many cities, practical approaches for integrating ES in decision-making process are needed.

Methods: We apply remote sensing techniques (integrating LiDAR data with high-resolution multispectral imagery) and combined these with supplementary spatial data to develop a replicable approach for assessing the role of urban vegetation (including invasive alien plants) in providing ES and ecosystem disservices (EDS). We identify areas denoting potential management trade-offs based on the spatial distribution of ES and EDS using a local-scale case study in the city of Cape Town, South Africa. Situated within a global biodiversity hotspot, Cape Town must contend with widespread invasions of alien plants (especially trees and shrubs) along with complex socio-political challenges. This represents a useful system to examine the challenges in managing ES and EDS in the context of urban plant invasions.
\end{abstract}

Results: Areas of high ES provision (for example carbon sequestration, shade and visual amenity) are characterized by the presence of large trees. However, many of these areas also result in numerous EDS due to invasions of alien trees and shrubs - particularly along rivers, in wetlands and along the urban edge where tall alien trees have established and spread into the natural vegetation (for example increased water consumption, increased fire risk and reduced soil quality). This suggests significant trade-offs regarding the management of species and the ES and EDS they provide.

Conclusions: The approach applied here can be used to provide recommendations and to guide city planners and managers to fine-tune management interventions at local scales to maximise the provision of ES.

Keywords: Biodiversity, Biological invasions, Ecosystem disservices, Ecosystem services, Remote sensing, Trade-offs, Tree invasions, Urban plant invasions

\footnotetext{
* Correspondence: lukepotgieter2@gmail.com

${ }^{1}$ Centre for Invasion Biology, Department of Botany and Zoology,

Stellenbosch University, Private Bag X1, Matieland 7602, South Africa

Full list of author information is available at the end of the article
} 


\section{Background}

Global urbanisation is increasing rapidly, placing enormous pressures on natural resources within and around urban centres. Satisfying the increasing demand for ecosystem services (ES), ensuring human well-being, and preventing the accelerating loss of biodiversity in and around urban areas remains a significant challenging (Haase et al. 2014). ES assessments are important for determining the vulnerability and resilience of urban areas and their residents to potential disruptions in the generation of ES when exposed to change (Gómez-Baggethun and Barton 2013).

Urban vegetation, particularly trees, provide many benefits that can enhance the well-being of urban residents (Jim and Chen 2008; Nowak et al. 2008; Escobedo et al. 2010). These include provisioning services such as food, water and timber; regulating services that positively affect climate, floods and water quality; cultural services that provide recreational, aesthetic, and spiritual benefits; and supporting services such as soil formation, photosynthesis, and nutrient cycling. However, urban ecosystems also generate functions, processes and attributes that can result in perceived or real negative impacts on human well-being (such as aesthetic, economic, environmental, health and social problems), termed ecosystem disservices (EDS) (Roy et al. 2012; Shackleton et al. 2016; Potgieter et al. 2017; Vaz et al. 2017).

Mapping urban vegetation and the ES and EDS they provide is important for decision makers and managers, as it helps them identify areas to prioritise for management. However, mapping plant species in urban environments presents numerous challenges due to their finescale spatial variation (Welch 1982) and high species diversity (native and alien), often representing novel ecosystems in terms of their composition (Wu 2014). Research demonstrating the potential of high-resolution images for assessing urban ecosystems functions and services is still emerging (e.g. Derkzen et al. 2015; Alonzo et al. 2016; Maragno et al. 2018; Zhao et al. 2019). Global and regional studies, although useful for international policy and science have been conducted at too coarse a resolution to be very useful for the management of services at local planning levels. Through freely accessible remotely-sensed data at higher resolutions and more robust analytical tools, remote sensing technology can make important contributions to multi-scale urban ecological assessments (Mathieu et al. 2007; Salehi et al. 2012; Raciti et al. 2014). Land cover information from remote sensing is a suitable starting point. By supplementing urban landscape features with additional data, the state of urban ecosystems and their capacities to supply ES can be assessed and mapped at different spatial scales.
Urban floras comprise a high proportion of alien tree species, many of which were intentionally introduced to provide, augment or restore ES (Potgieter et al. 2017). A trend in human preferences for particular plant traits has led to an increase in the proportion of alien trees in many urban areas around the world (Dickie et al. 2014), compounded by escaped woody ornamentals (Potgieter et al. 2017). Many alien tree taxa have subsequently spread and become invasive, threatening the delivery of ES (van Wilgen et al. 2008; van Wilgen 2012) and creating novel suites of EDS such as increased safety and security risks (Potgieter et al. 2018, 2019a). Understanding the ES-EDS dichotomy in the context of urban landscapes is important for promoting the development of resilient and sustainable cities (Carpenter et al. 2006; Liu et al. 2007). Decisions around managing invasive alien plants (IAPs) (sensu Richardson et al. 2000) in urban areas are fundamentally determined by their capacity to create negative impacts (EDS) and provide benefits (ES) (Vaz et al. 2017; Potgieter et al. 2018). Managing urban ecosystems to enhance the provisioning of ES while reducing EDS is a major challenge. Approaches aimed at optimising specific ES exclusively may exacerbate associated EDS, and those aimed solely at reducing EDS may reduce ES (Shackleton et al. 2016). For example, planting Black Locust (Robinia pseudoacacia L., Fabaceae) in urban areas for aesthetic purposes, shade, or to provide resources for honey-producing bees, may also provide EDS such as altered soil fertility and reduced species richness (Marozas et al. 2015). Given the limited resources available for assessing urban ES and EDS in many cities, practical approaches that integrate ES and EDS in the decision-making process are needed.

Predicting the effect of IAPs on a given ES is challenging as our knowledge of the mechanisms by which IAPs affect ES remain limited (Charles and Dukes 2007; Pejchar and Mooney 2009), and the metrics used to quantify urban ES (particularly in the context of IAPs) are still crude (Naidoo et al. 2008; Bennett et al. 2009). This lack of understanding on how to measure and predict the effects of IAPs on ES, particularly in urban areas, limits our ability to effectively prioritize and manage invasions. Remotely sensed maps of biological invasions may be used to inform ES assessments. Although many methods have been proposed for quantifying urban ES (e.g. Gómez-Baggethun and Barton 2013), many at fine spatial scales (e.g. Wurster and Artmann 2014; Haas and Ban 2016), few studies have attempted to combine remote sensing technologies to infer ES provided by IAPs in an urban context.

This study aims to develop a replicable approach to assess the role of urban vegetation (including IAPs) in providing ES and EDS at a local-scale, using the city of Cape Town as a case study. We apply remote sensing 
techniques (integrating LiDAR data with high resolution multispectral imagery) and supplementary spatial data to identify areas of high ES (and EDS) provision. We discuss the trade-offs associated with managing ES and EDS and the challenges in developing and implementing IAP management in urban areas. The approach applied in this study can be adopted by managers in all urban settings to guide the selection and prioritization of areas for IAP and/or ES management at the local scale.

\section{Methods}

\section{Study area}

The study site comprises an area $\left( \pm 2 \mathrm{~km}^{2}\right.$ in extent) in the residential suburb of Hout Bay, located in the city of Cape Town, South Africa (Fig. 1). It is bordered by Table Mountain National Park in the east and by the Atlantic Ocean to the south. The dominant natural vegetation in the city is fynbos, a short shrubland vegetation type which forms part of the Cape Floristic Region and holds exceptionally high diversity and endemism (Cowling et al. 1996). The fynbos biome is characteristically depauperate of native trees while widespread invasions of alien trees and shrubs such as Australian acacias, hakeas and pines dominate many parts of the landscape (Cowling and Richardson 1995), threatening the delivery of ES (van Wilgen et al. 2008; van Wilgen 2012). For example, Acacia saligna which was introduced to stabilise shifting sands has spread far beyond sites of formal plantings; it now negatively impacts biodiversity, surface water runoff, and exacerbates wildfires (van Wilgen and Richardson 1985; Le Maitre et al. 2002; Yelenik et al. 2004, 2007). However, despite the negative impacts of IAPs, some species remain beneficial to many urban residents (Gaertner et al. 2016; Potgieter et al. 2019b) namely through recreation, shade and visual amenity. This situation provides a unique opportunity to examine the applicability of remote sensing techniques for the spatially-explicit assessment of the role of urban vegetation (especially alien trees) in providing ES (and EDS) within this fine scale urban context.

Following the spatially entrenched apartheid form of South African cities, Cape Town remains highly divided, socially and spatially (Watson 2009). Rapid growth in informal settlements is a prominent feature of urbanisation in South Africa - a vestige of apartheid policies and practices. While most informal settlements are located on the urban peripheries or in and around areas of lowcost housing, some have developed in middle- to upperclass neighbourhoods, such as Hout Bay (see Ballard 2004). Three very disparate communities are currently located within Hout Bay. The mostly white middle- to upper income residents reside in the valley and along the mountain slopes in houses that reflect a high socioeconomic position. Another community close to the harbour consists of both low-income coloured residents who reside in hostels and flats, and middle-income white and coloured residents, who live higher up the slopes of Hangberg in an area known as Hout Bay Heights. The third community, which has developed most recently, is the informal settlement of Imizamo Yethu comprising mostly low-income Black African residents. Established on an old forestry site in 1991 to accommodate people who were illegally occupying land elsewhere in Hout

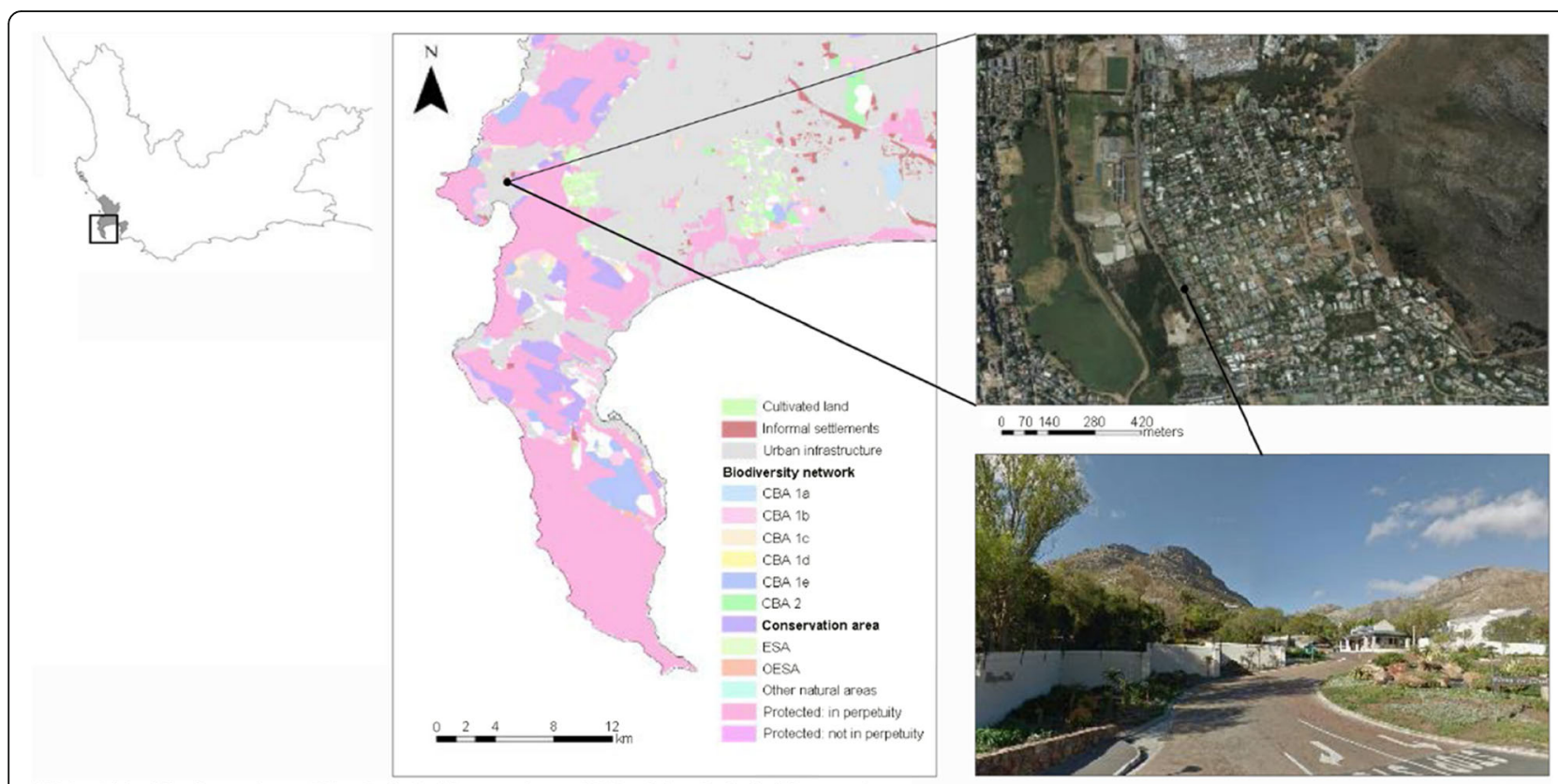

${ }^{*}$ CBA - Critical Biodiverse Areas; ESA - Ecological Support Areas; OESA - Other Ecological Support Areas.

Fig. 1 Location of the study area $\left( \pm 2 \mathrm{~km}^{2}\right)$ within the city of Cape Town municipal boundary in the Western Cape, South Africa 
Bay, Imizamo Yethu is characterized by poor basic service provision (e.g. education, housing, nutrition and healthcare), declining living conditions, environmental unsustainability, and poverty.

The study site has several key features that make it a useful study system: a) a range of land cover/land uses; b) significant socio-economic stratification; c) the urbanwildland interface; d) diversity and abundance of alien and native vegetation; and e) different plant invasion densities within the urban fabric and outside the urban edge.

\section{Analytical framework}

We developed an approach which combines remote sensing techniques (integrating LiDAR data with highresolution multispectral imagery) and supplementary spatial data (such as OpenStreetMap) with invasive alien species density data to assess the role of urban vegetation (including invasive alien plants) in providing ES and EDS at a local scale (Fig. 2). We identified areas with potential management trade-offs based on the spatial distribution of ES and EDS using a local-scale case study in the city of Cape Town, South Africa.

\section{LiDAR data and multispectral imagery}

The LiDAR (Light Detection and Ranging) system is a remote sensing method that uses light in the form of a pulsed laser to measure ranges (variable distances) to the Earth. It provides three-dimensional data with high

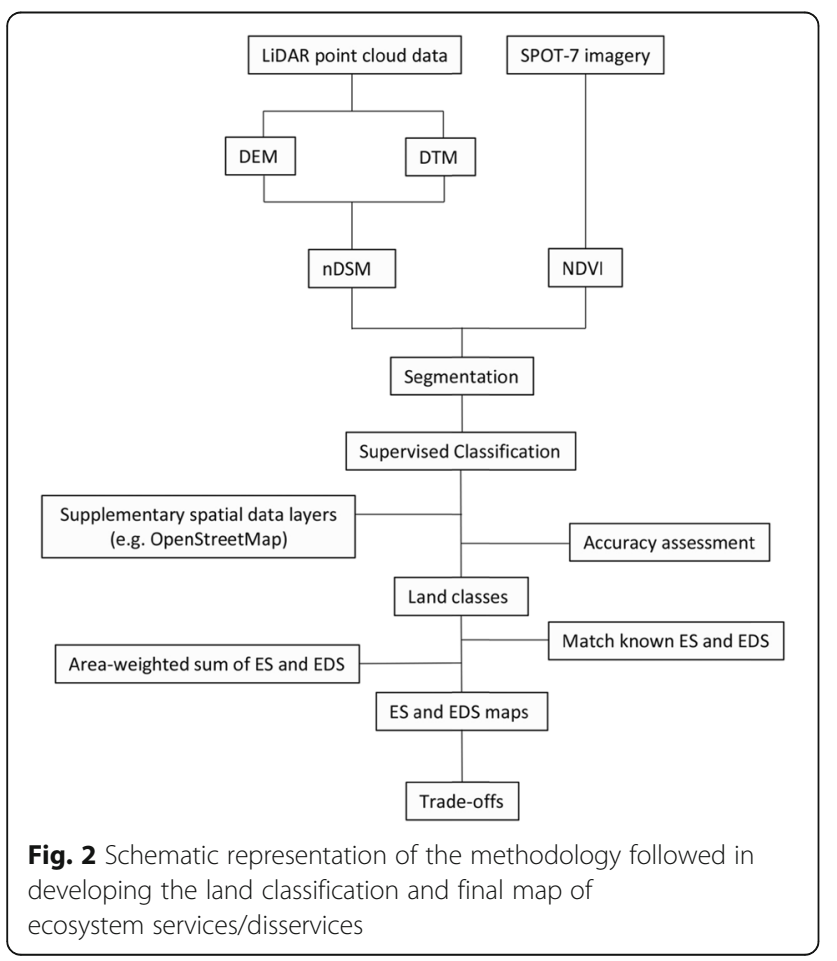

levels of horizontal and vertical accuracy. A key advantage of LiDAR over traditional optical sensors is its ability to estimate the heights of trees and shrubs with high vertical accuracy. There are, however, difficulties in accurately classifying vegetation from other land cover features such as buildings based solely on height information. Therefore, both multispectral satellite imagery and height information obtained from LiDAR data should be combined for accurate classification of detailed vegetation components. The airborne LiDAR data collected in February 2014 was provided by the Centre for Geographic Analysis and SPOT-7 images (consisting of red, green, blue and near-infrared image bands; $1.5 \mathrm{~m}$ spatial resolution) were acquired from the South African Space Agency (SANSA) (image acquisition: 11 November 2016).

Using ArcGIS 10.4, a normalized digital surface model (nDSM) was generated from LiDAR cloud point data (with a spatial resolution of $1.5 \mathrm{~m}$ ) to extract absolute height information by subtracting the digital surface model (DSM) from the digital terrain model (DTM). The nDSM represents the relative object height information for features, i.e., the LiDAR data has been corrected relative to the bare earth terrain. The next step involved calculating the Normalized Difference Vegetation Index (NDVI) on the near-infrared band and red band of the SPOT-7 image. All pixels with NDVI greater than 0.25 were considered to meet the threshold for containing vegetation and were included in the analysis. The methodology followed to develop the land classification and final ecosystem service-disservice maps is outlined in Fig. 2.

For the segmentation and classification of the LiDARderived nDSM and SPOT-7 imagery, the object-based image analysis software eCognition ${ }^{\circ}$ Developer 8.7 (Definiens 2005) was used. We first used multiresolution segmentation to identify objects with correlated characteristics in terms of reflectance and height. In this step, we fused the nDSM and the NDVI derived from the SPOT-7 imagery for the segmentation process. This method identifies geographical features using scale homogeneity parameters obtained from the SPOT-7 imagery spectral reflectance and the height value of the nDSM. Smoothness was adjusted to optimize each segment's spectral homogeneity and spatial complexity. Segments were classified by a supervised method into the following six classes based on the mean nDSM height and NDVI in each object: 'Bare ground': nDSM $<0.25 \mathrm{~m}$, NDVI <0.25; 'Grass': nDSM $<0.25 \mathrm{~m}$, NDVI $>=0.25$; 'Shrubs': $\mathrm{nDSM}>=0.25 \mathrm{~m}<3 \mathrm{~m}, \quad \mathrm{NDVI}>=0.25$; 'Infrastructure': nDSM $>=0.25 \mathrm{~m}$, NDVI $<0.25$; 'Trees': $n$ nSM $>=3.0 \mathrm{~m}<10 \mathrm{~m}$, NDVI $>=0.25$; 'Tall trees': $\mathrm{nDSM}>=10 \mathrm{~m}$, NDVI $>=0.25$. The final land classifications are detailed in Fig. 3a. 
a)
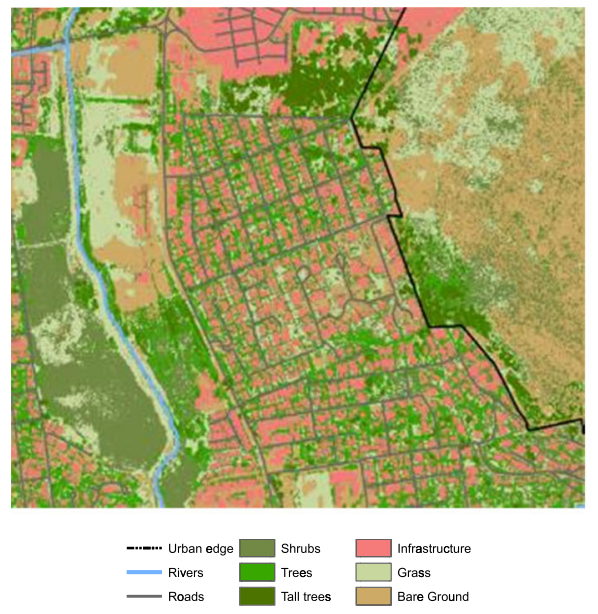

c)

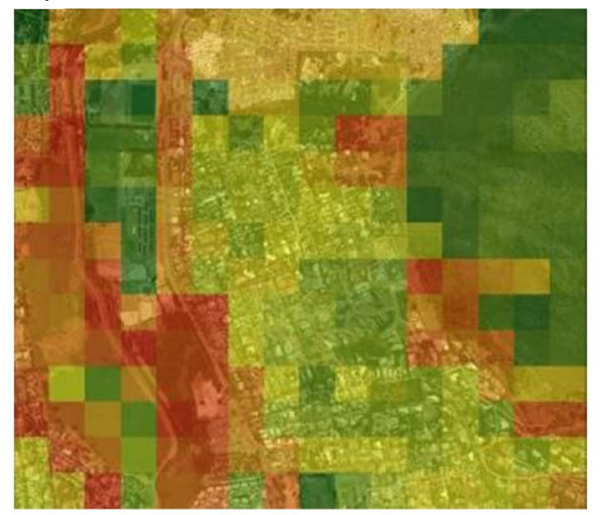

Low
Ecosystem Disservices b)
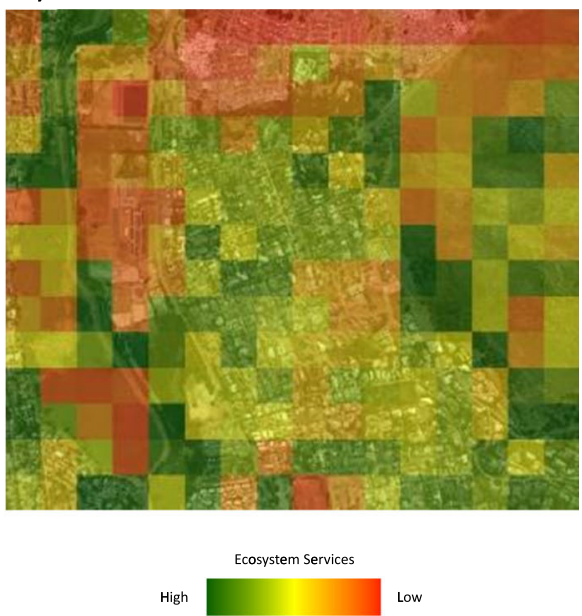

d)

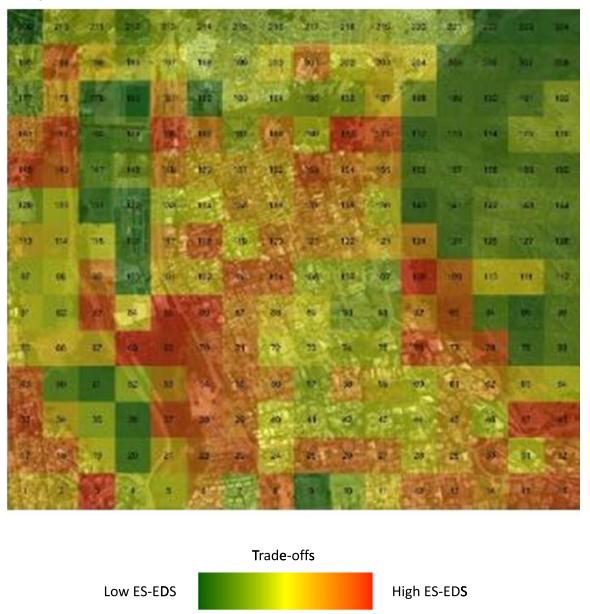

Fig. 3 a Land classification following LiDAR data and SPOT-7 image fusion; b Areas of high to low ecosystem service provision (per $100 \mathrm{~m}$ grid cell); $\mathbf{c}$ Areas of high to low ecosystem disservice provision (per $100 \mathrm{~m}$ grid cell); $\mathbf{d}$ Ecosystem service-disservice dichotomy showing areas of high to low ecosystem service-disservice provision - denoting potential management trade-offs

A classification accuracy assessment was carried out using a class area-weighted, stratified random sample of 168 points and validated using ground truthing (performed from 20 to 21 August 2018). The points selected for each class were spatially dispersed and proportional to their importance in terms of area covered. The final land classification map was adjusted to account for the classification errors. A confusion matrix was produced, and the overall accuracy and the kappa coefficient was calculated.

\section{Ecosystem service and disservices}

Urban areas undergo significant land cover (and land use) changes. Such changes impact the capacity of ecosystems to provide ES to urban residents. Land cover was used as a proxy measure of ES - mapping land cover gives an initial indication of the potential ES and EDS provision or reduction. Remote sensing serves as a useful tool for land use/land cover classification.

ES and EDS were matched with our final land classification derived from the remotely sensed LiDAR and multispectral image classification, aerial photographs, and supplementary spatial data (OpenStreetMap). ES and EDS were categorised according to Potgieter et al. (2017) and those associated with each respective land class applicable to the study area are detailed in Table 1. A grid comprising 100 by $100 \mathrm{~m}$ cells was laid over the study area. The area covered by each land class within each grid cell was calculated and weighted based on the sum of corresponding ES and EDS detailed in Table 1. As no information was available on the importance of the different ES or EDS they were weighted equally in the assessment (Wainger et al. 2010). For example, a grid cell may comprise tall trees in a residential garden which provide a range of ES: 
Table 1 Accuracy matrix for the land classification

\begin{tabular}{|c|c|c|c|c|c|c|c|}
\hline \multirow[t]{2}{*}{ Class } & \multicolumn{6}{|l|}{ Ground truth } & \multirow{2}{*}{$\begin{array}{l}\text { User } \\
\text { accuracy } \\
(\%)\end{array}$} \\
\hline & Bare ground & Grass & Shrubs & Trees & Tall trees & Infrastructure & \\
\hline Bare Ground & 22 & 2 & 1 & 1 & 0 & 3 & 75.86 \\
\hline Grass & 4 & 20 & 2 & 0 & 0 & 0 & 76.92 \\
\hline Shrubs & 0 & 2 & 36 & 1 & 0 & 0 & 92.31 \\
\hline Trees & 0 & 0 & 1 & 31 & 1 & 0 & 93.94 \\
\hline Tall Trees & 0 & 0 & 0 & 2 & 17 & 0 & 89.47 \\
\hline Infrastructure & 3 & 0 & 1 & 0 & 0 & 18 & 81.82 \\
\hline Producer's accuracy (\%) & 75.86 & 83.33 & 87.80 & 88.57 & 94.44 & 85.71 & \\
\hline
\end{tabular}

Total accuracy: $85.71 \%$; kappa coefficient: 0.826

recreation, spiritual interaction, visual amenity, provision of sense-of-place, increased property value, shade provision, climate regulation, improved air quality, carbon sequestration, stormwater runoff mitigation, habitat provision, increased nutrient cycling, pollination, primary production and soil formation. Conversely, they may also result in EDS: increased maintenance costs, generation of green waste, increased water consumption, pollen allergies, infrastructural damage and safety hazard. Such ES and EDS were acquired from the literature and cited in Table 2 accordingly. The area-weighted sum of ES and EDS per land class within the grid cell was calculated.

Separate maps detailing areas of low to high provision of ES and EDS were developed and combined to form an overall depiction of ES-EDS provision. Areas with high provision of both ES and EDS are likely to result in tradeoffs regarding the management of species and the ES and EDS they provide. This was achieved by subtracting the overall (net) area-weighted EDS from the net areaweighted ES for each grid cell. Trade-offs occur when the increase in one ES results in a reduction of another desirable service or an increase in a disservice, while synergies exist when the enhancement of one ES has a positive effect on another (Haase et al. 2012, Dobbs et al. 2014). In the context of this study, EDS refer to both a reduction in ES (e.g. reduced soil quality) and/or the creation of a new EDS (e.g. infrastructural damage). While the relationship between biodiversity and the provision of ES remains contested (e.g. Egoh et al. 2009), most studies associate high species richness with a high levels of ES provision (Balvanera et al. 2006; Benayas et al. 2009). Maintaining biodiversity is considered as an efficient way to enhance ES. Our study area comprises key biodiversity areas (Fig. 1) and these were included in the ES-EDS spatial assessment i.e. areas of high biodiversity correspond to areas of high ES provision.

\section{Additional information and tools}

We incorporated supplementary spatial data from different sources to improve the accuracy of our classification (see Table 3). These included spatial data from OpenStreetMap (OSM), invasive alien plant (IAP) density data from the City of Cape Town Invasive Species Unit (Biodiversity Management Branch; hereafter ISU), and multiple spatial data layers obtained from the City of Cape Town's open data portal.

\section{OpenStreetMap}

Volunteered geographic information (VGI) is a method for collecting and disseminating geospatial data primarily acquired through the voluntary efforts of citizens. One of the most utilized and popular VGI-platforms is OpenStreetMap (OSM) (http://www.osmfoundation.org), a project providing freely exportable maps of cities worldwide. Data in OSM are obtained from a community of volunteers whom create spatial data by tracing noncopyrighted, aerial imagery or generating data directly using GPS devices. Maps include information on roads, railways, buildings, waterways and points of interests such as parks, commercial centres, leisure centres and commercial activities. While the coverage and quality of such data may vary across locations, it has the potential to provide an important research tool, particularly where data from more traditional sources are limited or nonexistent.

The OSM vector data for the study area was downloaded in July 2018 using the ArcGIS Editor for OSM in ArcGIS 10.4. All relevant OSM thematic layers were included in the classification process.

\section{Invasive alien plants}

We obtained spatial data (acquisition date August 2016) on IAP density from the ISU; such data is used to inform invasive species management across the city (Gaertner et al. 2016). The ISU conducts clearing operations in areas managed by multiple departments within the city, including many conservation areas. At each area identified as a priority for control operations, the ISU conducts a site assessment in which management units (MU) are delineated and surveyed and baseline 
Table 2 Ecosystem services and disservices associated with urban vegetation within the study area

\begin{tabular}{|c|c|c|c|}
\hline $\begin{array}{l}\text { Ecosystem } \\
\text { service } \\
\text { category }\end{array}$ & Ecosystem services & Example & Reference \\
\hline \multirow[t]{6}{*}{ Cultural } & Recreation & $\begin{array}{l}\text { Picnicking under tall shade-providing trees } \\
\text { (e.g. Pinus pinea) }\end{array}$ & Potgieter et al. (2019b) \\
\hline & $\begin{array}{l}\text { Physical, intellectual and spiritual } \\
\text { interactions with nature, including aesthetic } \\
\text { values, inspiration and cognitive } \\
\text { development, and spiritual enrichment }\end{array}$ & $\begin{array}{l}\text { Well managed urban green spaces with } \\
\text { abundant vegetation }\end{array}$ & Bastian et al. (2012); Dobbs et al. (2011) \\
\hline & $\begin{array}{l}\text { Visual amenity, ornamental purposes and } \\
\text { landscape re-greening }\end{array}$ & Private residential gardens & $\begin{array}{l}\text { Dickie et al. (2014); Carruthers et al. (2011); } \\
\text { Kull et al. (2011); Le Maitre et al. (2011); } \\
\text { Shackleton et al. (2016) }\end{array}$ \\
\hline & Provision of a 'sense of place' & & Dickie et al. (2014) \\
\hline & Heritage & $\begin{array}{l}\text { Pinus pinea trees planted in the } \\
\text { seventeenth century by the early settlers, } \\
\text { have significant heritage value }\end{array}$ & Gaertner et al. (2016) \\
\hline & Increased property values & & Soares et al. (2011) \\
\hline \multirow[t]{5}{*}{ Provisioning } & Firewood & $\begin{array}{l}\text { Trees such as Acacia sp., Eucalyptus sp. or } \\
\text { Pinus sp. can be used for firewood }\end{array}$ & Dickie et al. (2014) \\
\hline & Construction material & $\begin{array}{l}\text { Trees such as Eucalyptus sp. or Pinus sp. } \\
\text { can be used for poles }\end{array}$ & Dickie et al. (2014) \\
\hline & Medicinal value & Essential oils provided by Eucalyptus sp. & \\
\hline & Fodder & Eucalyptus camaldulensis used as fodder & Bernholt et al. (2009) \\
\hline & Food & $\begin{array}{l}\text { Eucalyptus sp. (especially E. cladocalyx) are } \\
\text { important for honey production }\end{array}$ & \\
\hline \multirow[t]{10}{*}{ Regulating } & Shade & $\begin{array}{l}\text { Shade from tall trees with wide canopy } \\
\text { such as Pinus pinea }\end{array}$ & Potgieter et al. (2019b); \\
\hline & Climate regulation & $\begin{array}{l}\text { Cooling effects (by transpiration) of street } \\
\text { trees such as Platanus } \times \text { acerifolia }\end{array}$ & Jim and Chen (2009) \\
\hline & Air quality & $\begin{array}{l}\text { Reduced emissions of air pollutants by } \\
\text { Platanus } \times \text { acerifolia }\end{array}$ & McPherson (2003) \\
\hline & Flood attenuation & Wetlands & \\
\hline & Barrier & Pinus sp. used as a barrier plant & \\
\hline & Carbon sequestration & $\begin{array}{l}\text { Trees such as Platanus } \times \text { acerifolia } \\
\text { sequester carbon }\end{array}$ & Potgieter et al. (2017) \\
\hline & Nitrogen fixation & Acacia sp. fix nitrogen, enriching the soil & $\begin{array}{l}\text { Qiu (2015); Dickie et al. (2014); van Wilgen } \\
\text { and Richardson (2014); de Wit et al. (2001) }\end{array}$ \\
\hline & Erosion control & $\begin{array}{l}\text { Erosion control by trees such Ailanthus } \\
\text { altissima }\end{array}$ & $\begin{array}{l}\text { Sladonja et al. (2015); Kowarik and Säumel } \\
\text { (2007) }\end{array}$ \\
\hline & Energy saving & $\begin{array}{l}\text { Changes in building energy use from } \\
\text { shade trees such as Platanus } \times \text { acerifolia }\end{array}$ & McPherson (2003) \\
\hline & Stormwater runoff mitigation & & \\
\hline \multirow[t]{5}{*}{ Supporting } & Habitat provision & $\begin{array}{l}\text { Tall alien trees such as eucalypts and pines } \\
\text { provide nesting sites for birds with which } \\
\text { many urban dwellers can enjoy } \\
\text { encounters. }\end{array}$ & McPherson et al. (2011) \\
\hline & Nutrient cycling & & \\
\hline & Pollination & $\begin{array}{l}\text { Robinia pseudoacacia in urban areas provides } \\
\text { resources for honey producing bees }\end{array}$ & Hausman et al. (2015) \\
\hline & Primary production & & \\
\hline & Soil formation & & \\
\hline
\end{tabular}


Table 2 Ecosystem services and disservices associated with urban vegetation within the study area (Continued)

\begin{tabular}{|c|c|c|c|}
\hline $\begin{array}{l}\text { Ecosystem } \\
\text { service } \\
\text { category }\end{array}$ & Ecosystem services & Example & Reference \\
\hline \multirow[t]{3}{*}{$\begin{array}{l}\text { Cultural and } \\
\text { Aesthetic }\end{array}$} & Loss of sense of place and aesthetic values ${ }^{\mathrm{a}}$ & $\begin{array}{l}\text { Loss of sense of place and aesthetic values } \\
\text { due to the presence of invasive alien plant } \\
\text { species }\end{array}$ & de Wit et al. (2001); Le Maitre et al. (2011) \\
\hline & Unattractive species or landscapes & $\begin{array}{l}\text { Ugly' landscapes dominated by Acacia } \\
\text { species. Neglected vacant lots overgrown } \\
\text { with 'weedy' vegetation }\end{array}$ & Carruthers et al. (2011) \\
\hline & Obscuring good views & $\begin{array}{l}\text { Tall trees such as Pinus sp. can block good } \\
\text { views }\end{array}$ & Roy et al. (2012) \\
\hline \multirow[t]{3}{*}{$\begin{array}{l}\text { Economic } \\
\text { Problem }\end{array}$} & Increased maintenance costs & $\begin{array}{l}\text { Grooming of street trees or sweeping up } \\
\text { of leaf litter in streets }\end{array}$ & Roy et al. (2012) \\
\hline & Cost of irrigation & $\begin{array}{l}\text { Alien plants in gardens require supplementary } \\
\text { irrigation during the dry season }\end{array}$ & Roy et al. (2012) \\
\hline & Reduced property value $e^{a}$ & $\begin{array}{l}\text { Invasive plants blocking good views can } \\
\text { reduce property prices }\end{array}$ & Roy et al. (2012) \\
\hline \multirow{5}{*}{$\begin{array}{l}\text { Environmental } \\
\text { Problem }\end{array}$} & Generating green waste & Increased green waste from gardens & Roy et al. (2012) \\
\hline & Increased water consumption & $\begin{array}{l}\text { Increased water consumption by alien and } \\
\text { invasive trees such as Acacia sp. and } \\
\text { Eucalyptus sp. }\end{array}$ & $\begin{array}{l}\text { Carruthers et al. (2011); Kull et al. (2011); } \\
\text { Le Maitre et al. (2002, 2011); van Wilgen } \\
\text { and Richardson (2014) }\end{array}$ \\
\hline & Reduced soil quality ${ }^{a}$ & $\begin{array}{l}\text { Modification of soil quality and promotion } \\
\text { of soil erosion }\end{array}$ & de Wit et al. (2001); Shackleton et al. (2016) \\
\hline & $\begin{array}{l}\text { Disruption of soil-nutrient cycling, carbon } \\
\text { and nitrogen fixation }{ }^{\mathrm{a}}\end{array}$ & $\begin{array}{l}\text { Invasive alien trees and shrubs such as } \\
\text { Acacia sp. fix nitrogen }\end{array}$ & $\begin{array}{l}\text { Yelenik et al. (2004); Gaertner et al. (2014); Qiu } \\
\text { (2015) }\end{array}$ \\
\hline & $\begin{array}{l}\text { Displacement of native plant species / } \\
\text { Reduced species richness }{ }^{\mathrm{a}}\end{array}$ & $\begin{array}{l}\text { Invasive alien trees and shrubs spreading } \\
\text { into natural areas can disrupt native } \\
\text { fynbos plant species and continued spread } \\
\text { may reduce native species richness }\end{array}$ & $\begin{array}{l}\text { Carruthers et al. (2011); Dickie et al. (2014); } \\
\text { Kull et al. (2011); Le Maitre et al. (2011); } \\
\text { Shackleton et al. (2016); van Wilgen and } \\
\text { Richardson (2014); Vicente et al. (2013) }\end{array}$ \\
\hline \multirow[t]{4}{*}{ Health } & Reduced air quality ${ }^{a}$ & $\begin{array}{l}\text { Emissions of Biogenic Volatile Organic } \\
\text { Compounds reducing air quality }\end{array}$ & Potgieter et al. (2017) \\
\hline & $\begin{array}{l}\text { Increasing attack by associated insects and } \\
\text { other animals }\end{array}$ & $\begin{array}{l}\text { Areas with dense vegetation can harbour } \\
\text { potentially dangerous animals such as } \\
\text { venomous snakes }\end{array}$ & Roy et al. (2012) \\
\hline & Pollen allergies & $\begin{array}{l}\text { Pollen allergy and/or dermatitis caused by } \\
\text { A. altissima, Acacia dealbata, Cortaderia } \\
\text { selloana, and Schinus terebinthifolius }\end{array}$ & Pyšek and Richardson (2010) \\
\hline & Poisoning & $\begin{array}{l}\text { Cardiac problems and poisoning from } \\
\text { Echium plantagineum }\end{array}$ & Pyšek and Richardson (2010) \\
\hline \multirow[t]{2}{*}{$\begin{array}{l}\text { Leisure and } \\
\text { Recreation }\end{array}$} & Reduced recreation ${ }^{\mathrm{a}}$ & $\begin{array}{l}\text { Presence of invasive species considered } \\
\text { unpleasant for recreation }\end{array}$ & Vaz et al. (2017) \\
\hline & Physical injury & $\begin{array}{l}\text { Physical injury through contact with plant } \\
\text { spines or thorns }\end{array}$ & $\begin{array}{l}\text { Pyšek and Richardson (2010); Shackleton et al. } \\
\text { (2016) }\end{array}$ \\
\hline Material & Infrastructural damage & $\begin{array}{l}\text { Roots of Ailanthus altissima damaging } \\
\text { paved surfaces and boundary walls }\end{array}$ & $\begin{array}{l}\text { Celesti-Grapow and Blasi (2004); } \\
\text { Potgieter et al. (2019b) }\end{array}$ \\
\hline \multirow[t]{2}{*}{$\begin{array}{l}\text { Safety and } \\
\text { Security }\end{array}$} & Fears of insects and other animals & $\begin{array}{l}\text { Areas with dense vegetation can be invoke } \\
\text { fear due to the possible presence of } \\
\text { distasteful animals such as insects or snakes }\end{array}$ & Vaz et al. (2017) \\
\hline & Increased crime risk & $\begin{array}{l}\text { Criminal activity in dense vegetation close } \\
\text { to informal settlement }\end{array}$ & Potgieter et al. (2019a) \\
\hline $\begin{array}{l}\text { Safety and } \\
\text { Security / } \\
\text { Environmental } \\
\text { Problem }\end{array}$ & $\begin{array}{l}\text { Increased fire risk (safety risk to } \\
\text { infrastructure, but also impacting on native } \\
\text { plants due to increased frequency and } \\
\text { intensity of fires) }\end{array}$ & $\begin{array}{l}\text { Increased fire risk due to tree invasions } \\
\text { along the urban edge }\end{array}$ & $\begin{array}{l}\text { Gaertner et al. (2014); Le Maitre et al. (2011); } \\
\text { van Wilgen and Richardson (2014); Potgieter } \\
\text { et al. (2018) }\end{array}$ \\
\hline $\begin{array}{l}\text { Safety and } \\
\text { Security / } \\
\text { Material }\end{array}$ & Safety hazard & Tall trees blown over in strong winds & Potgieter et al. (2019b) \\
\hline
\end{tabular}


Table 3 Supplementary spatial data and corresponding sources included in the classification process

\begin{tabular}{ll}
\hline Spatial Data & Data Source \\
\hline Indigenous vegetation remnants & City of Cape Town data portal; South African National Biodiversity Institute (SANBI) BGIS data portal \\
Biodiversity Network (CBA Rank) & SANBI BGIS data portal \\
Dams, aquifers, rivers, wetlands & City of Cape Town data portal; Invasive Species Unit (August 2016) \\
Flood prone areas & Directorate: Disaster Risk Reduction; Invasive Species Unit (August 2016) \\
Roads, buildings, points of interest & OpenStreetMap \\
Urban edge & City of Cape Town data portal \\
Community parks & City of Cape Town data portal \\
Greenbelts & City of Cape Town data portal \\
IAP density data & Invasive Species Unit (August 2016) \\
\hline
\end{tabular}

information captured (see Potgieter et al. 2018). All IAPs present within each MU are listed and categorised according to predefined size categories used to describe the age of plants. The density of alien plant cover (\% cover) is also estimated for each MU.

IAP cover was delineated using 1) density data from ISU site assessments and 2) the total area of trees and tall trees $(>3 \mathrm{~m})$ outside of the urban edge (as per our land classification) - fynbos is typically depauperate of trees (Rundel et al. 2014) and plant species taller than 3 $\mathrm{m}$ are likely to be alien (Richardson et al. 1996). The area covered by these delineations within each grid cell was calculated and weighted based on the sum of corresponding ES and EDS detailed in Table 2. The total area for all MU's within the AOI was 4.6 ha.

\section{Results}

An accuracy assessment of the land classification map yielded an accuracy of $85.71 \%$ and a Kappa coefficient of 0.826 (Table 1). The 'Bare ground' class yielded the lowest accuracy with a user's accuracy of $75.86 \%$, followed by 'Grass' at $76.92 \%$. The discrimination of bare ground proved problematic at times as it was confused with dry or patchy grass. Furthermore, there were several treecovered areas that were confused with shrubs or tall trees, largely due to minor height discrepancies.

\section{Ecosystem services}

Areas of high ES provision were characterized by the presence of large trees, which can sequester more carbon, provide more shade for people, and serve as habitat for fauna (Table 2). These areas occur predominantly along the urban edge (comprising invasive alien trees which have established and spread into the natural vegetation) and in the gardens of (affluent) residential properties (Fig. 3b). Other areas of high ES provision include urban green spaces, such as community parks, river networks and wetlands. Such areas are important in creating recreational spaces, reducing flood risk and cooling urban micro-climates (Table 2).
Areas of lowest ES provision occur in the township and informal settlement of Imizamo Yethu which is characterised by little to no vegetation, dense informal structures, and bare ground. Other areas of low ES provision included infrastructure such as large building surrounded by impervious surfaces and bare ground (Fig. 3b).

\section{Ecosystem disservices}

Areas resulting in high EDS coincide with areas densely invaded by IAPs - particularly where alien plants invade along rivers and within wetlands (Fig. 3c). Other areas with high EDS occur along the urban edge where tall alien trees have established and started to spread into the natural vegetation. EDS include increased water consumption (environmental problems), increased fire and crime risk (safety and security), reduced soil quality (environmental problems), or a loss of sense of place and aesthetic values (cultural and aesthetic) (Table 2).

Moderate EDS are associate with areas comprising trees and shrubs (native or alien) such as private gardens, public open space and vacant lots. This is due to EDS such as increased water consumption (environmental problems), increased maintenance costs (economic problems), safety hazard (safety and security), infrastructural damage (material) or obscuring good views (cultural and aesthetic) (Table 2).

Areas associated with low EDS occur outside the urban edge in uninvaded natural vegetation. Areas comprising dense infrastructure (such as the informal settlement of Imizamo Yethu), impervious surfaces or bare ground resulted in moderate EDS. Such areas are more acutely associated with low ES provision (e.g. lack of shade, recreation and sense of place) than high EDS, however, characteristics of such an environment can create EDS (e.g. bare compacted ground or impervious surfaces can enable flooding and increase the ambient temperature).

\section{Trade-offs}

Areas with high supply of both ES and EDS are likely to result in trade-offs regarding the management of species 
and the ES and EDS they provide (Fig. 3d). Many of the associated EDS are due to the presence of IAPs - several grid cells identified as important for the provision of ES, comprise IAPs. For example, grid cell 68 contains a river and wetland (vital for ES such as water provision, groundwater recharge and flood attenuation), but is densely invaded by alien aquatic plants (which some residents may find aesthetically appealing; Potgieter et al. 2019b), such as Nasturtium officinale and Myriophyllum aquaticum, which can reduce stream flows and water quality (Fig. 3d). Grid cell 108 comprises many species of alien trees and shrubs such as Acacia spp., Eucalyptus spp. and Pinus spp., which provide ES such as carbon sequestration, firewood, habitat provision and shade. However, these taxa are invasive and create EDS such as increased water consumption, increased fire risk and the displacement of native plant species (van Wilgen and Richardson 2014).

Residential gardens represent areas of moderate ESEDS provision, i.e. there is moderate provision of both ES and EDS (Fig. 3d). A high proportion of urban vegetation provides many key ES, such as carbon sequestration, shade, and visual amenity. However, there are several associated EDS, such as increased water consumption, production of green waste, and increased maintenance and clean-up costs.

\section{Discussion}

Developing approaches that can holistically map ES (and EDS) have been identified as a major research gap (de Groot et al. 2010a,b). We assessed multiple ES and EDS, integrating LiDAR data with high resolution multispectral imagery and applying supplementary spatially-explicit data proxies at a local scale to identify areas of high and low ES and EDS provision. In doing so, we also identified areas denoting potential management trade-offs. This approach can be applied to different urban areas where baseline information on urban vegetation is available and can be used to prioritise the conservation of areas of high provision of ES to maintain human well-being. Conversely, areas of high EDS or low ES provision could be prioritised for management interventions that restore and improve human well-being.

\section{Invasive alien plants and the ecosystem service - disservice dichotomy}

Areas of high ES provision such as residential property gardens and urban green spaces are characterized by the presence of large trees (Fig. 3). Urban trees provide diverse aesthetic, economic, health, psychological and social benefits for urban residents (Roy et al. 2012) including: reduction in carbon pollution, improving air quality, reducing storm-water flooding, conserving energy, and reducing noise
(Table 2). However, many of these areas also result in numerous EDS (e.g. increased fire risk and water consumption) due to invasions of alien trees and shrubs - particularly along rivers and within wetlands and along the urban edge where tall alien trees have established and started to spread into the natural vegetation. This suggests significant trade-offs regarding the management of species and the ES and EDS they provide.

Urban planners and managers are faced with many trade-offs in the decision-making process as each area (regional or local) is governed by different ecological, economic, and social variables. Stakeholders in urban areas often have opposing views regarding the benefits and negative impacts of IAPs, and consequently, conflicts over the management of IAPs are emerging (Dickie et al. 2014; Gaertner et al. 2017). IAPs may provide provisioning ES (e.g. firewood), but significantly threaten biodiversity, which can lead to conflicts over whether to manage for the former or the latter (van Wilgen 2012). Therefore, many IAPs within urban areas may need to be tolerated at specific sites for a combination of social and pragmatic reasons (Gaertner et al. 2016). Careful evaluation of the ES-EDS dichotomy in the context of urban plant invasions may allow conflicts to be mitigated and managed in more efficient ways (Dickie et al. 2014; Potgieter et al. 2017).

Several grid cells identified as important for the provision of ES, comprise IAPs which can in turn result in numerous EDS (Fig. 4). Residential properties along the urban edge share a border with fynbos vegetation here (Alston and Richardson 2006), and these properties serve as sources of alien plant propagules, which disperse, establish and spread into the surrounding natural vegetation, threatening biodiversity. While providing several ES such as firewood and carbon sequestration, the increase in biomass resulting from alien plant invasions close to urban infrastructure represents a substantial fire risk (Fig. 5), threatening property and the safety of people (van Wilgen and Scott 2001; van Wilgen et al. 2012). Furthermore, invasive alien trees and shrubs alter the vegetation structure (forming dense stands and growing taller than the surrounding fynbos vegetation; van Wilgen and Richardson 1985), providing cover for vagrants and those engaged in criminal activity. Potgieter et al. (2018) found that factors related to safety and security are most important for setting spatially-explicit management priorities in Cape Town. Accordingly, invaded areas along the urban edge (e.g. Figure 5) should receive a high priority for management. Areas identified as important in the provision of ES (e.g. urban green spaces and surrounding natural vegetation) should be monitored to ensure the continued provision of ES and maintenance of biodiversity. 


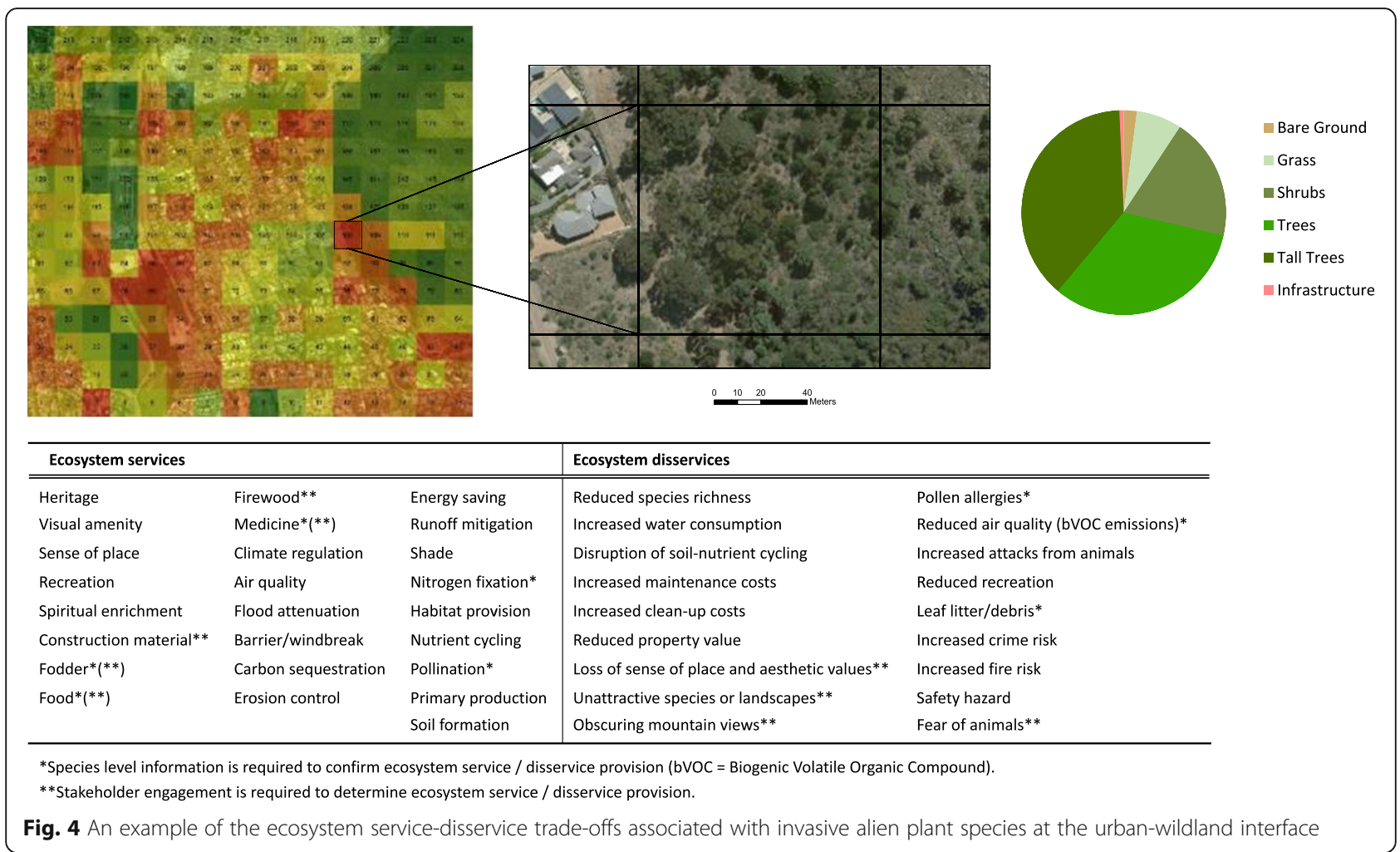

\section{Decision-making and management}

The nature of people and their discount rates that favour immediate over delayed gratification may be driving decisions about ES, even when such decisions might interfere with ES that are necessary for the long-term sustainability of human well-being (Foley et al. 2005).

The emphasis on provisioning ES may be due to their more tangible and easily quantifiable character, whereas the importance of cultural, regulating, and supporting services are more difficult to quantify (Potgieter et al. 2017). Particularly, research on cultural ES are generally subjective and socially value-laden (related more to the individual than to ecosystem conditions) as each individual or each group of individuals has different value systems and priorities. Various aspects like experience, habits, belief systems, behavioural traditions, and general political and socio-economic status should be considered (Vaz et al. 2017; Shackleton et al. 2019). Social values related to preferences, importance, measures and principles, and assessment need to be plural, participatory and best embedded within transdisciplinary research (Pascual et al. 2017). Indeed, community engagement is crucial, and quantifications based on interviews, questionnaires or additional information sources can strengthen ES

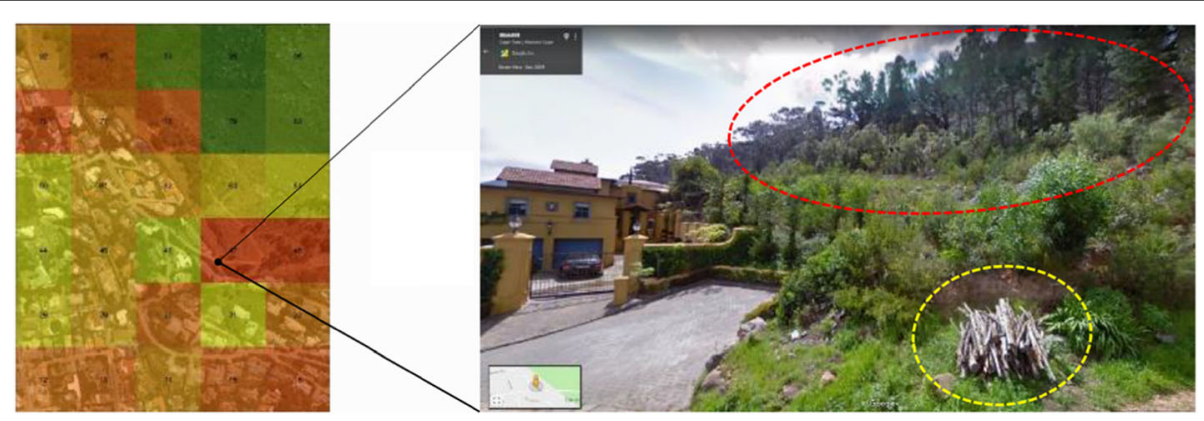

Fig. 5 Google Street View can be used to determine key vegetation characteristics and associated ecosystem services and disservices at specific locations. Tall, dense stands of invasive Acacia sp., Eucalyptus sp. and Pinus sp. behind a residential property on the urban edge are visible; these present a substantial fire risk (imagery date: 09/2009). A pile of wood (likely to be used as firewood) collected from these invasive stands is also clearly visible, highlighting an ecosystem service provided by the invasive alien trees 
assessments and better inform management strategies (Sherrouse et al. 2011). Research on the application of remote sensing in the field of alien species and ES continues to progress as technology and our understanding of the ways in which ES are mediated by alien species improves (e.g. Lafortezza and Giannico 2017; Pettorelli et al. 2017; Vaz et al. 2019).

Each urban area presents a unique set of challenges requiring city-specific management strategies (Irlich et al. 2017). The challenge in prioritising areas for management at the local scale is to weigh factors relating to biodiversity conservation, ES (and EDS) and social tradeoffs. For example, managers must decide whether to prioritise areas which have negative indirect long-term impacts on biodiversity and regulating and supporting services (such as increased soil erosion and reduced soil quality) or to prioritise areas based on the negative direct short-term impacts on provisioning services (such as water supply).

Decisions must be made on whether to manage for enhanced ES provision, or to minimise EDS - high priority areas for management include those which result in EDS (including a reduction in ES provision). For example, areas along the urban edge invaded with alien trees and shrubs which negatively impact on biodiversity and ES (such as the displacement of native plant species and reduced soil quality) and result in EDS such as increase fire and crime risk (Potgieter et al. 2018, 2019b). Such decisions are largely context-specific, and managers need to consider the knock-on effects when managing to reduce EDS or enhance specific ES, as other ES may be indirectly disrupted, or novel EDS created. For example, planting trees in the informal settlement of Imizamo Yethu with the intention of providing ES (such as shade) and enhancing human well-being may have the opposite effect as trees may blow over in high winds and increase the risk of fires. Such decisions need to be transparent and must consider opinions of a wide range of stakeholders including the public and those involved in urban planning and ecosystem management decisions (Novoa et al. 2018).

Careful consideration must also be given to the existing supply and demand of ES beneficiaries and their perceptions of ecosystem components (Burkhard et al. 2012; Shackleton et al. 2019). Stakeholder engagement is needed to gauge the ES demand and this information can be aligned with spatial assessments of ES provision to identify areas that have the potential to unlock the required ES to meet this demand. Importantly, however, ES demand is likely to be highly variable and context-specific (e.g. along the socioeconomic gradient) (Syrbe and Grunewald 2017). Understanding the ways in which people perceive nature is also crucial for developing effective management strategies to conserve and maintain biodiversity, ES and human well-being (Shackleton et al. 2019). This is especially important in urban areas which generally have a greater number and diversity of stakeholders compared to rural areas (Gaston et al. 2013). Indeed, perceptions of urban vegetation and the ES and EDS they provide can differ markedly between individuals or groups of people (Shackleton et al. 2016; Kueffer and Kull 2017; Potgieter et al. 2019b).

\section{Socio-economic context}

Socio-economic conditions within the urban milieu influence the spatial heterogeneity in the provision of ES (de Groot et al. 2010a, b). Areas of lowest ES provision occur in the township and informal settlement area of Imizamo Yethu which is characterised by little to no vegetation, dense informal structures, impervious surfaces and bare ground (Fig. 3b). These features result in low ES provision and can facilitate flooding and increase the ambient temperature.

Affluent areas have the capacity and resources to invest in green infrastructure such as plantings in private gardens. In so doing they can contribute to the provision of additional ES (ES synergies) such as carbon sequestration, improved air quality and stormwater runoff mitigation (from which other residents may benefit). However, lower income areas such as informal settlements do not have the same capacity or resources and rely solely on existing ES provided by the immediate environment. Indeed, this is a common theme in many rapidly urbanising African cities in which many people are still highly reliant on natural resources (including IAPs). The urban poor lack an adequate supply of basic services like electricity, healthcare, sanitation, waste disposal, and water (Goodness and Anderson 2013). Additional measures are needed to improve the supply of ES to these areas. One recommendation may be to advocate for the planting of beneficial, native, drought-resistant perennial shrubs such as honeybush (Cyclopia spp.) or buchu (Agathosma spp.), which can provide multiple ES (e.g. medicine; Petersen et al. 2012) with relatively few associated EDS. However, the practicalities of implementing such measures may prove challenging. The careful evaluation of the demands of the communities is required as there are likely to be divergent viewpoints and competing objectives. Engaging with the community is therefore a key part of the process. Similarly, managing to reduce EDS in the surrounding areas requires rigorous social assessments to avoid potential conflicts of interest. For example, clearing invasive alien trees nearby may affect the livelihoods of Imizamo Yethu residents as they may utilize these species for firewood or construction material. 


\section{Methodological considerations}

Some online resources enable a range of new remote sensing possibilities, including the use of interactive onthe-ground virtual views. Foremost among these is Google's Street View (GSV) - a free-access web technology featured in Google Maps and Google Earth. GSV provides interactive georeferenced panoramic photographs, taken at short intervals by high-resolution cameras placed on the roof of a moving car, along many roads around the world. This provides on-the-ground imagery for sites close to roads, most extensively in urban areas.

GSV can serve as a useful supplementary tool in ES assessments (e.g. Richards and Edwards 2017), particularly in urban areas. For example, once an ES- or EDSproviding area has been identified, GSV images of the site can be examined to determine accessibility, characteristics of street vegetation such as the proportion of streetscape 'green' coverage, and in some cases individual plant species. Occasionally, a direct link between surrounding vegetation and ES can be detected (Fig. 5).

\section{Limitations}

Direct remote sensing of ES is challenging - ES are often intangible in that they are defined by ecosystem functions and processes that involve a temporal component. Biodiversity and habitat functions are particularly difficult to map remotely as they depend largely on species composition which must be measured using inventories and ground data collection (Gillespie et al. 2008). Regulating services, characterized as being of indirect use, provide the conditions that allow other directly used ES (e.g. provision of firewood) to exist (Abson and Termansen 2011). Similarly, supporting services do not directly benefit people, but are essential to the functioning of ecosystems and are therefore indirectly responsible for all other services (Haines-Young and Potschin 2010). Consequently, these services are more difficult to quantify (Rodriguez et al. 2006), particularly in urban settings.

Many ES are difficult to effectively conform to land cover as an ES proxy, as genus- or species-level information is required. For example, food (provisioning), nitrogen fixation (regulating) and pollination (supporting) require detailed information on the species traits facilitating the provision of ES (Table 1). As a result, such ES may be overrepresented in this approach. The diversity of species in urban areas makes species-level image classification particularly challenging. Coarse spatial and spectral resolutions make it difficult to separate native and alien species in mixed species assemblages. Species mapping efforts are usually limited to a small subset of species that are canopy dominants and that are sufficiently distinct to enable remote detection. The presence of many alien species (mainly herbaceous plants) may not be discernible even using the newest high-resolution sensors (e.g. GeoEye-1). In addition, phenological changes of vegetation due to the presence of alien species might not be recognizable if there is no distinct flowering pattern because of the coarse spectral resolution of high spatial resolution images.

Acquiring affordable data at an appropriate resolution around the same time period may be challenging when following the approach developed here. Data should be acquired at the highest spatial resolution possible to ensure accurate classification, and all datasets should, as much as is possible, be temporally aligned. Ensuring the data at least matches seasonally, should be the minimum requirement.

Some ES are more significant than others (McPherson et al. 2005; Stoffberg et al. 2010; Soares et al. 2011). For example, while the value of energy savings, carbon dioxide reduction and air pollutant deposition in Lisbon were comparable to several other USA cities, the large values associated with stormwater runoff reduction and increased property value were considerably greater than values obtained in US cities (Soares et al. 2011). No information is available on the importance of different ES and EDS for our study area and these were consequently not weighted in our assessment. It is important to assign priorities to specific ES and EDS prior to performing spatial assessments.

\section{Conclusions}

Multiple interacting environmental and socio-economic factors complicate IAP management efforts in urban areas across the globe. The challenge is for IAP managers to overcome such barriers to effectively manage urban plant invasions and ensure the continued provision of ES that are essential for human well-being. However, management decisions need to carefully consider the socio-economic ties associated with IAPs and such decisions need to be based on an understanding of plural values, be participatory and rooted within transdisciplinary research.

This study presents a reproducible and spatially-explicit assessment of ES and EDS and demonstrates an effective approach for guiding urban planners and managers to improve ES provision at the local-scale. The study also unpacks potential management trade-offs and conflicts of interest resulting from the complexities of the ES-EDS dichotomy, which requires urgent consideration to improve resilience through urban policy and planning.

\section{Abbreviations}

DSM: Digital Surface Model; DTM: Digital Terrain Model; EDS: Ecosystem disservices; ES: Ecosystem services; GSV: Google Street View; IAP: Invasive alien plants; ISU: Invasive Species Unit; LiDAR: Light Detection and Ranging; MU: Management Unit; nDSM: Normalised Digital Surface Model; NDVI: Normalized Difference Vegetation Index; OSM: OpenStreetMap; 
SANSA: South African Space Agency; VGI: Volunteered Geographic Information

\section{Acknowledgements}

Funding for this work was provided by the DST-NRF Centre of Excellence for Invasion Biology, the Working for Water Programme through their collaborative research project on "Integrated Management of invasive alien species in South Africa", and the National Research Foundation, South Africa (grant 85417 to DMR). We thank the Invasive Species Unit for providing invasive plant density data. We also thank Divan Vermeulen from the Centre for Geographical Analysis, Stellenbosch University, for providing LiDAR data and additional guidance.

\section{Authors' contributions}

LJP, POF and DMR conceived the study; LJP performed the analyses and wrote the first draft; all authors contributed critically to successive drafts and gave final approval for publication.

\section{Funding}

Funding for this work was provided by the DST-NRF Centre of Excellence for Invasion Biology and the Working for Water Programme through their collaborative research project on "Integrated Management of invasive alien species in South Africa" and the National Research Foundation, South Africa (grant 85417 to DMR).

\section{Availability of data and materials}

The datasets used and/or analysed during the current study are available from the corresponding author on request.

\section{Ethics approval and consent to participate}

Not applicable.

\section{Consent for publication}

Not applicable.

\section{Competing interests}

The authors declare that they have no competing interests.

\section{Author details}

${ }^{1}$ Centre for Invasion Biology, Department of Botany and Zoology, Stellenbosch University, Private Bag X1, Matieland 7602, South Africa. ${ }^{2}$ Nürtingen-Geislingen University of Applied Sciences (HFWU), Schelmenwasen 4-8, 72622 Nürtingen, Germany. ${ }^{3}$ Natural Resources and Environment CSIR, Biodiversity and ES Research Group, P.O. Box 320, Stellenbosch 7599, South Africa. ${ }^{4}$ Percy FitzPatrick Institute of African Ornithology, University of Cape Town, Rondebosch, South Africa.

Received: 2 April 2019 Accepted: 11 September 2019

Published online: 28 October 2019

\section{References}

Abson DJ, Termansen M (2011) Valuing ecosystem services in terms of ecological risks and returns. Conserv Biol 25:250-258

Alonzo M, McFadden JP, Nowak DJ, Roberts DA (2016) Mapping urban forest structure and function using hyperspectral imagery and lidar data. Urban For Urban Green 17:135-147

Alston KP, Richardson DM (2006) The roles of habitat features, disturbance, and distance from putative source populations in structuring alien plant invasions at the urban/wildland interface on the cape peninsula, South Africa. Biol Conserv 132:183-198

Ballard R (2004) Middle class neighbourhoods or 'African kraals'? The impact of informal settlements and vagrants on post-apartheid white identity. Urban Forum 15:48-73

Balvanera P, Pfisterer AB, Buchmann N, He JS, Nakashizuka T, Raffaelli D, Schimid B (2006) Quantifying the evidence for biodiversity effects on ecosystem functioning and services. Ecol Lett 9:1146-1156

Bastian O, Haase D, Grunewald K (2012) Ecosystem properties, potentials and services - the EPPS conceptual framework and an urban application example. Ecol Indic 21:7-16.
Benayas JMR, Newton AC, Diaz A, Bullock JM (2009) Enhancement of biodiversity and ecosystem services by ecological restoration: a meta-analysis. Science 325:1121-1124

Bennett EM, Peterson GD, Gordon LJ (2009) Understanding relationships among multiple ecosystem services. Ecol Lett 12:1394-1404

Bernholt H, Kehlenbeck K, Gebauer J, Buerkert A (2009) Plant species richness and diversity in urban and peri-urban gardens of Niamey, Niger. Agr Syst 77:159-179

Burkhard B, Kroll F, Nedkov S, Muller F (2012) Mapping ecosystem service supply, demand and budgets. Ecol Indic 21:17-29

Carpenter SR, De Fries R, Dietz T, Mooney HA, Polasky S, Reid WV, Scholes RJ (2006) Millennium ecosystem assessment: research needs. Science 314:257-258

Carruthers J, Robin L, Hattingh JP, Kull CA, Rangan H, van Wilgen BW (2011) A native at home and abroad: the history, politics, ethics and aesthetics of acacias. Divers Distrib 17:810-821

Celesti-Grapow L, Blasi C (2004) The role of alien and native weeds in the deterioration of archaeological remains in Italy. Weed Technol 18:1508-1513

Charles H, Dukes JS (2007) Impacts of invasive species on ecosystem services. In: Nentwig W (ed) Biological Invasions. Springer, Berlin, pp 217-238

Cowling R, Richardson D (1995) Fynbos: South Africa's unique floral kingdom. Fernwood Press, Cape Town

Cowling RM, Macdonald IAW, Simmons MT (1996) The cape peninsula, South Africa. Biodivers Conserv 5:527-550

de Groot RS, Alkemade R, Braat L, Hein L, Willemen L (2010a) Challenges in integrating the concept of ecosystem services and values in landscape planning, management and decision making. Ecol Complex 7:260-272

de Groot RS, Fisher B, Christie M, Aronson J, Braat L, Gowdy J, Haines-Young R, Maltby E, Neuville A, Polasky S, Portela R, Ring I (2010b) Integrating the ecological and economic dimensions in biodiversity and ecosystem service valuation. In: Kumar P (ed) The economics of ecosystems and biodiversity: ecological and economic foundations. Earthscan, London, pp 9-40

de Wit MP, Crookes DJ, van Wilgen BW (2001) Conflicts of interest in environmental management: estimating the costs and benefits of a tree invasion. Biol Invasions 3:167-178

Definiens (2005) eCognition User Manual, Version 3, http://www.definiens.com/ documents/index.htm. Accessed 15 Mar 2018

Derkzen ML, van Teeffelen AJA, Verburg PH (2015) Quantifying urban ecosystem services based on high-resolution data of urban green space: an assessment for Rotterdam, the Netherlands. J Appl Ecol 52:1020-1032

Dickie I, Bennett B, Burrows L, Nuñez M, Peltzer D, Porté A, Richardson DM, Rejmánek M, Rundel P, van Wilgen BW (2014) Conflicting values: ecosystem services and invasive tree management. Biol Invasions 16:705-719

Dobbs C, Escobedo FJ, Zipperer WC (2011) A framework for developing urban forest ecosystem services and goods indicators. Landscape Urban Plan 99:196-206

Dobbs C, Kendal D, Nitschke CR (2014) Multiple ecosystem services and disservices of the urban forest establishing their connections with landscape structure and sociodemographics. Ecol Indic 43:44-55

Egoh B, Reyers B, Rouget M, Bode M, Richardson DM (2009) Spatial congruence between biodiversity and ecosystem services in South Africa. Biol Conserv 142:553-562

Escobedo F, Varela S, Zhao M, Wagner JE, Zipperer W (2010) Analyzing the efficacy of subtropical urban forests in offsetting carbon emissions from cities. Environ Sci Policy 13:362-372

Foley JA, DeFries R, Asner GP, Barford C, Bonan G, Carpenter SR, Chapin FS, Coe MT, Daily GC, Gibbs HK, Helkowski JH, Holloway T, Howard EA, Kucharik CJ, Monfreda C, Patz JA, Prentice IC, Ramankutty N, Snyder PK (2005) Global consequences of land use. Science 309:570-574.

Gaertner M, Biggs R, Te Beest M, Hui C, Molofsky J, Richardson DM (2014) Invasive plants as drivers of regime shifts: identifying high-priority invaders that alter feedback relationships. Divers Distrib 20:733-744

Gaertner M, Larson BMH, Irlich UM, Holmes PM, Stafford L, van Wilgen BW, Richardson DM (2016) Managing invasive species in cities: a framework from Cape Town, South Africa. Landscape Urban Plan 151:1-9

Gaertner M, Novoa A, Fried J, Richardson DM (2017) Managing invasive species in cities: a decision support framework applied to Cape Town. Biol Invasions 19: 3707-3723

Gaston KJ, Ávila-Jiménez ML, Edmondson JL (2013) Managing urban ecosystems for goods and services. J Appl Ecol 50:830-840

Gillespie TW, Foody GM, Rocchini D, Giorgi AP, Saatchi S (2008) Measuring and modeling biodiversity from space. Prog Phys Geogr 32:203-221

Gómez-Baggethun E, Barton DN (2013) Classifying and valuing ecosystem services for urban planning. Ecol Econ 83:235-245 
Goodness J, Anderson P (2013) Local assessment of Cape Town: navigating the management complexities of urbanization, biodiversity, and ecosystem services in the cape floristic region. In: Elmqvist T, Fragkias $M$, Goodness J, Güneralp B, Marcotullio PJ, McDonald RI, Parnell S, Schewenius M, Sendstad M, Seto KC, Wilkinson C (eds) Urbanization, biodiversity and ecosystem services: challenges and opportunities. Springer, Dordrecht, pp 461-484

Haas J, Ban Y (2016) Mapping and monitoring urban ecosystem services using multitemporal high-resolution satellite data. IEEE J Sel Topics Appl Earth Obs Remote Sens 10:669-680

Haase D, Schwarz N, Strohbach M, Kroll F, Seppelt R (2012) Synergies, tradeoffs, and losses of ecosystem services in urban regions: an integrated multiscale framework applied to the Leipzig- Halle region, Germany. Ecol Soc 17:102-123

Haase J, Jacob A, Ban Y (2014) Urban ecosystems mapping from spaceborne high-resolution optical data. Proceedings of Dragon 3 Mid-Term Results Symposium, Chengdu 26-29 May 2014 (ESA SP-724, November 2014) ISBN 978-92-9221-288-9

Haines-Young RH, Potschin M (2010) The links between biodiversity, ecosystem services and human well-being. In: Raffaelli D, Frid C (eds) Ecosystem ecology: a new synthesis, BES ecological reviews series, CUP. Cambridge University Press, Cambridge, pp 110-139

Hausmann SL, Petermann JS, Rolff J (2016) Wild bees as pollinators of city trees. Insect Conserv Divers 9:97e107. https://doi.org/10.1111/icad.12145

Irlich UM, Potgieter L, Stafford L, Gaertner M (2017) Recommendations for municipalities to become compliant with national legislation on biological invasions. Bothalia 47(2):a2156. https://doi.org/10.4102/abc.v47i2.2156.

Jim CY, Chen WY (2008) Assessing the ecosystem service of air pollutant removal by urban trees in Guangzhou (China). J Environ Manage 88:665-676

Jim CY, Chen WY (2009) Ecosystem services and valuation of urban forests in China. Cities 26:187-194

Kowarik I, Säumel I (2007) Biological flora of Central Europe: Ailanthus altissima (Mill.) Swingle. Perspect Plant Ecol Evol Syst 8:207-237

Kueffer C, Kull CA (2017) Non-native species and the aesthetics of nature. In: Vilà M, Hulme PE, Ruiz G (eds) Impact of biological invasions on ecosystem services. Springer, Berlin, pp 311-324

Kull CA, Shackleton CM, Cunningham PJ, Ducatillon C, Dufour-Dror J-M, Esler KJ, Friday JB, Gouveia AC, Griffin AR, Marchante E, Midgley SJ, Pauchard A, Rangan H, Richardson DM, Rinaudo T, Tassin J, Urgenson LS, von Maltitz GP, Zenni RD, Zylstra MJ (2011) Adoption, use and perception of Australian acacias around the world. Divers Distrib 17:822-836

Lafortezza R, Giannico V (2017) Combining high-resolution images and LiDAR data to model ecosystem services perception in compact urban systems. Ecol Indic 96:87-98

Le Maitre DC, Gaertner M, Marchante E, Ens EJ, Holmes PM, Pauchard A, O'Farrell PJ, Rogers AM, Blanchard R, Blignaut J, Richardson DM (2011) Impacts of invasive Australian acacias: implications for management and restoration. Divers Distrib 17:1015-1029

Le Maitre DC, van Wilgen BW, Gelderblom CM, Bailey C, Chapman RA, Nel JA (2002) Invasive alien trees and water resources in South Africa: case studies of the costs and benefits of management. For Ecol Manage 160:143-159

Liu J, Dietz T, Carpenter SR, Alberti M, Folke C, Moran E, Pell AN, Deadman P, Kratz T, Lubchenco J, Ostrom E, Ouyang Z, Provencher W, Redman CL, Schneider SH, Taylor WW (2007) Complexity of coupled human and natural systems. Science 317:1513-1516

Maragno D, Gaglio M, Robbi M, Appiotti F, Fano EA, Gissi E (2018) Fine-scale analysis of urban flooding reduction from green infrastructure: an ecosystem services approach for the management of water flows. Ecol Model 386:1-10

Marozas V, Cekstere G, Laivins M, Straigyte L (2015) Comparison of neophyte communities of Robinia pseudoacacia L. and Acer negundo L. in the eastern Baltic Sea region cities of Riga and Kaunas. Urban For Urban Green 14:826-834

Mathieu R, Freeman C, Aryal J (2007) Mapping private gardens in urban areas using object-oriented techniques and very high-resolution satellite imagery. Landscape Urban Plan 81:179-192

McPherson EG (2003) A benefit-cost analysis of ten street tree species in Modesto, California, U.S. J Arboric 29:1-8

Mcpherson G, Simpson JR, Peper PJ, Maco SE, Xiao Q (2005) Municipal forest benefits and costs in five US cities. J For 103:411-416

McPherson EG, Simpson JR, Xiao Q, Wu C (2011) Million trees Los Angeles canopy cover and benefit assessment. Landsc Urban Plan 99:40-50.
Naidoo R, Balmford A, Costanza R, Fisher B, Green RE, Lehner B, Malcolm TR, Ricketts TH (2008) Global mapping of ecosystem services and conservation priorities. Proc Natl Acad Sci U S A 105:9495-9500

Novoa A, Shackleton RT, Canavan S, Cybèle C, Davies SJ, Dehnen-Schmutz K, Fried J, Gaertner M, Geerts S, Griffiths C, Kaplan H, Kumschick S, Le Maitre DC, Measey GJ, Nunes AL, Richardson DM, Robinson TB, Touza J, Wilson JRU (2018) A framework for engaging stakeholders on the management of alien species. J Environ Manage 205:286-297

Nowak DJ, Crane DE, Stevens JC, Hoehn RE, Walton JT, Bond J (2008) A groundbased method of assessing urban forest structure and ecosystem services. Arboric Urban For 34:347-358

Pascual U, Balvanera P, Díaz S, Pataki G, Roth E, Stenseke M, Watson RT, Dessane EB, Islar M, Kelemen E, Maris V, Quaas M, Subramanian SM, Wittmer H, Adlan A, Ahn S, Al-Hafedh YS, Amankwah E, Asah ST, Berry P, Bilgin A, Breslow SJ, Bullock C, Caceres D, Daly-Hassen H, Figueroa E, Golden CD, Gomez-Baggethun E, Gonzalez-Jimenez D, Houdet J, Keune H, Kumar R, Ma KP, May PH, Mead A, O'Farrell P, Pandit R, Pengue W, PichisMadruga R, Popa F, Preston S, Pacheco-Balanza D, Saarikoski H, Strassburg BB, van den Belt M, Verma M, Wickson F, Yagi N (2017) Valuing nature's contributions to people: the IPBES approach. Curr Opin Environ Sustain 26: 7-16

Pejchar L, Mooney HA (2009) Invasive species, ecosystem services and human wellbeing. Trends Ecol Evol 24:497-504

Petersen LM, Moll EJ, Collins R, Hockings MT (2012) Development of a compendium of local, wild-harvested species used in the informal economy trade, Cape Town, South Africa. Ecol Soc 17:26

Pettorelli N, Schulte to Bühne H, Tulloch A, Dubois G, Macinnis-Ng C, Queirós AM, Keith DA, Wegmann M, Schrodt F, Stellmes M, Sonnenschein R (2017) Satellite remote sensing of ecosystem functions: opportunities, challenges and way forward. Remote Sens Ecol Conserv 4:71-93

Pooley S (2014) Burning Table Mountain: An environmental history of fire on the Cape Peninsula. Palgrave Macmillan, Basingstoke.

Potgieter L, Gaertner M, Irlich UM, O'Farrell PJ, Stafford L, Vogt H, Richardson DM (2018) Managing urban plant invasions: a multi-criteria prioritization approach. Environ Manage 62:1168-1185

Potgieter LJ, Gaertner M, O'Farrell PJ, Richardson DM (2019a) Does vegetation structure influence criminal activity? Insights from Cape Town, South Africa. Front Biogeogr 11(1):e42035

Potgieter LJ, Gaertner M, O'Farrell PJ, Richardson DM (2019b) Perceptions of impact: invasive alien plants in the urban environment. J Environ Manage 229:76-87

Potgieter L, Kueffer C, Larson BMH, Livingston S, O'Farrell P, Gaertner M, Richardson DM (2017) Alien plants as mediators of ecosystem services and disservices in urban systems: a global review. Biol Invasions 19:3571-3588

Pyšek P, Richardson DM (2010) Invasive species, environmental change and management, and health. Annu Rev Env Resour 35:25-55

Qiu J (2015) A global synthesis of the effects of biological invasions on greenhouse gas emissions. Glob Ecol Biogeogr 24:1351-1362

Raciti SM, Hutyra LR, Newell JD (2014) Mapping carbon storage in urban trees with multi-source remote sensing data: relationships between biomass, land use, and demographics in Boston neighborhoods. Sci Total Environ 500-501: $72-83$

Richards DR, Edwards PJ (2017) Quantifying street tree regulating ecosystem services using Google street view. Ecol Indic 77:31-40

Richardson DM, Pyšek P, Rejmánek M, Barbour MG, Panetta DF, West CJ (2000) Naturalization and invasion of alien plants - concepts and definitions. Divers Distrib 6:93-107

Richardson DM, van Wilgen BW, Higgins SI, Trinder-Smith TH, Cowling RM, McKelly DH (1996) Current and future threats to biodiversity on the cape peninsula. Biodivers Conserv 5:607-647

Rodriguez JP, Beard TD, Bennett EM, Cumming GS, Cork SJ, Agard J, Dobson AP, Peterson GD (2006) Trade-offs across space, time, and ecosystem services. Ecol Soc 11:28

Roy S, Byrne J, Pickering C (2012) A systematic quantitative review of urban tree benefits, costs, and assessment methods across cities in different climatic zones. Urban For Urban Green 11:351-363

Rundel PW, Dickie IA, Richardson DM (2014) Tree invasions into treeless areas: mechanisms and ecosystem processes. Biol Invasions 16:663-675

Salehi B, Zhang Y, Zhong M, Dey V (2012) Object-based classification of urban areas using VHR imagery and height points ancillary data. Remote Sens (Basel) 4:2256-2276 
Shackleton CM, Ruwanza S, Sinasson Sanni GK, Bennett S, Lacy P, Modipa R, Mtati N, Sachikonye M, Thondhlana G (2016) Unpacking Pandora's box: understanding and categorising ecosystem disservices for environmental management and human wellbeing. Ecosystems 19:587-600

Shackleton RT, Richardson DM, Shackleton CM, Bennett B, Crowley S, DehnenSchmutz K, Estévez R, Fischer A, Kueffer C, Kull C, Marchante E, Novoa A, Potgieter LJ, Vaas J, Vaz AS, Larson BHM (2019) Explaining people's perceptions of invasive alien species: a conceptual framework. J Environ Manage 229:10-26

Sherrouse BC, Clement JM, Semmens DJ (2011) A GIS application for assessing, mapping, and quantifying the social values of ecosystem services. Appl Geogr 31:748-760

Sladonja B, Sušek M, Guillermic J (2015) Review on invasive tree of heaven (Ailanthus altissima (mill.) Swingle) conflicting values: assessment of its ecosystem services and potential biological threat. Environ Manag 56:1009-1034

Soares AL, Rego FC, Mcpherson EG, Simpson JR, Peper PJ, Xiao Q (2011) Benefits and costs of street trees in Lisbon, Portugal. Urban For Urban Green 10:69-78

Stoffberg GH, Van Rooyen MW, Van Der Linde MJ, Groeneveld HT (2010) Carbon sequestration estimates of indigenous street trees in the City of Tshwane, South Africa. Urban For Urban Green 9:9-14

Syrbe RU, Grunewald K (2017) Ecosystem service supply and demand - the challenge to balance spatial mismatches. Int J Biodivers Sci Manage 13:148-161

van Wilgen BW (2012) Evidence, perceptions, and trade-offs associated with invasive alien plant control in the Table Mountain National Park, South Africa. Ecol Soc 17:23

van Wilgen BW, Forsyth GG, Prins P (2012) The management of fire-adapted ecosystems in an urban setting: the case of Table Mountain National Park, South Africa. Ecol Soc 17:8

van Wilgen BW, Reyers B, Le Maitre DC, Richardson DM, Schonegevel L (2008) A biome-scale assessment of the impact of invasive alien plants on ecosystem services in South Africa. J Environ Manage 89:336-349

van Wilgen BW, Richardson DM (1985) The effects of alien shrub invasions on vegetation structure and fire behaviour in south African fynbos shrublands: a simulation study. J Appl Ecol 22:955-966

van Wilgen BW, Richardson DM (2014) Challenges and trade-offs in the management of invasive alien trees. Biol Invasions 16:721-734

van Wilgen BW, Scott DF (2001) Managing fires on the cape peninsula: dealing with the inevitable. J Mediterr Ecol 2:197e208

Vaz AS, Gonçalves JF, Pereira P, Santarém F, Vicente JR, Honrado JP (2019) Earth observation and social media: evaluating the spatiotemporal contribution of non-native trees to cultural ecosystem services. Remote Sens Environ 230: 111193

Vaz AS, Kueffer C, Kull CA, Richardson DM, Vicente JR, Kuhn I, Schroter M, Hauck J, Bonn A, Honrado JP (2017) Integrating ecosystem services and disservices: insights from plant invasions. Ecosyst Serv 23:94-107

Vicente JR, Pinto AT, Araújo MB, Verburg PH, Lomba A, Randin CF, Guisan A, Honrado JP (2013) Using life strategies to explore the vulnerability of ecosystem services to invasion by alien plants. Ecosystems 16:678-693

Wainger LA, King DM, Mack RN, Price EW, Maslin T (2010) Can the concept of ecosystem services be practically applied to improve natural resource management decisions? Ecol Econ 69:978-987

Watson V (2009) The planned city sweeps the poor away ... urban planning and 21st century urbanism. Prog Plan 72:151-193

Welch R (1982) Spatial resolution requirements for urban studies. Int J Remote Sens 2:139-146

Wu J (2014) Urban ecology and sustainability: the state-of-the-science and future directions. Landscape Urban Plan 125:209-221

Wurster D, Artmann M (2014) Development of a concept for non-monetary assessment of urban ecosystem services at the site level. Ambio 43:454-465

Yelenik SG, Stock WD, Richardson DM (2004) Ecosystem-level impacts of invasive alien nitrogen-fixing plants. Ecosystem and community-level impacts of invasive alien Acacia saligna in the fynbos vegetation of South Africa. Restor Ecol 12:44-51

Yelenik SG, Stock WD, Richardson DM (2007) Functional group identity does not predict invader impacts: differential effects of nitrogen-fixing exotic plants on ecosystem function. Biol Invasions 9:117-125

Zhao W, Li A, Huang Q, Gao Y, Li F, Zhang L (2019) An improved method for assessing vegetation cooling service in regulating thermal environment: a case study in Xiamen, China. Ecol Indic 98:531-542

\section{Submit your manuscript to a SpringerOpen ${ }^{\circ}$ journal and benefit from:}

- Convenient online submission

- Rigorous peer review

- Open access: articles freely available online

- High visibility within the field

- Retaining the copyright to your article

Submit your next manuscript at $\boldsymbol{\nabla}$ springeropen.com 